\title{
ANALISIS PENGELOLAAN KEUANGAN DAERAHDI KOTA JAYAPURA PADA ERA OTONOMI KHUSUS
}

\author{
Halomoan Hutajulu \\ Fakultas Ekonomi, Universitas Cenderawasih \\ halomoan.h@gmail.com
}

\begin{abstract}
The implementation of the Special Autonomy (Special Autonomy) in accordance with Law No. 21, 2001, is an effort to accelerate the development and distribution of areas in the city of Jayapura. Implementation OTSUS is the equation of regional autonomy of local governments and financial management. The purpose of this study to analyze the financial management aspects of the area in terms of effectiveness, and budget planning after special autonomy, and justice analyze budget allocations. Quantitative analysis of the research approach consisting of a horizontal analysis, vertical analysis, and conversion analysis. The results showed that the effectiveness of the financial management of Jayapura city district in the Special Autonomy less effective, analysis of revenue and revenue growth ratio high of 37.33 percent and lowest 6.07. Ratio highest balanced fund 49.55 percent in 2006. Highest expenditure ratio reached 47.13 percent. The results showed a tendency analyst highest revenue growth in 2009 of Rp45.103 Billion, followed by the highest propensity balanced fund Rp567.980 Billion in 2009, the trend of the highest expenditures Rp451.190 Billion in 2009, the highest real development expenditure Rp208.063 Billion in 2008, the highest absorbed construction Rp147.418 Billion in 2006. Financial planning area is under estimated to PAD, whereas the conversion of the budget shows the budget surplus in 2002 and 2007.
\end{abstract}

Keywords:Effectiveness, Budget Planning

\section{PENDAHULUAN}

\section{Latar Belakang}

Otonomi atau desentralisasi pada dasarnya merupakan transfer kekuasaan dan tanggung jawab pemerintah pusat kepada pemerintah daerah dalam bidang pelayanan publik serta bidang fiskal. Lahirnya desentralisasi tersebut ditandai dengan lahirnya Undang-Undang No.32 Tahun 2004 tentang Pemerintah Daerah dan Undang-Undang No.33 Tahun 2004 tentang Perimbangan Keuangan Antara Pemerintah Pusat dan Daerah. 
Melalui otonomi daerah ini diharapkan akan menciptakan kemandirian daerah, sehingga mempercepat dalam upaya mengejar ketertinggalan dengan daerah lain, serta terciptanya keberhasilan pembangunan di daerah. Dalam upaya menciptakan kemandirian daerah, Pendapatan Asli Daerah (PAD) merupakan salah satu alat yang dapat dipakai dalam menghimpun dana dalam penyusunan rencana pembangunan daerah.

Desentralisasi diperlukan untuk perbaikan efisensi ekonomi, efisiensi biaya, perbaikan infrastruktur, perbaikan akuntabilitas dan peningkatan mobilisasi dana (Suahasil dan Nurkholis 2006:134). Desentralisasi fiskal bertujuan untuk memberdayakan dan meningkatkan kemampuan perekonomian daerah,juga untuk menciptakan sistem pembiayaan yang adil, proporsional, rasional, transparan, partisipatif dan bertanggung jawab, serta untuk mengurangi kesenjangan pembangunan antar daerah (Riyanto 2005).

Ketergantungan pemerintah daerah kepada pemerintah pusat masih cukup tinggi hal tersebut sejalan dengan pendapat Adi (2005) dimana daerah-daerah yang memiliki kapasitas fiskal rendah akan mengalami tekanan fiskal yang kuat. Daerah dituntut untuk mengoptimalkan potensi pendapatan yang dimiliki dan salah satunya adalah dengan memberi porsi belanja daerah yang lebih besar untuk sektor produktif, maupun melalui ekstensifikasi dan intensifikasi sumber-sumber PAD yang baru dalam upaya membiayai program dan kegiatan pemerintah daerah dalam menjalankan roda pemerintahan maupun pelaksanakan pembangunan daerah.

Kota Jayapura sebagai salah satu daerah bagian dari Provinsi Papua yang merasakan langsung kekhususan dalam pengelolaan bidang pemerintahan dan bidang fiskal sebagaimana yang diamanatkan dalam Otonomi Daerah (OTDA) dan Otonomi Khusus (OTSUS) di Papua (UU No.21 Tahun 2001 tentang Otonomi Khusus di Provinsi Papua). Implementasi Pelaksanaan OTDA dan OTSUS mengharuskan pemerintah daerah Kota Jayapurauntuk menentukan prioritas program dan perencanaan pembangunan daerah dan kewenangan untuk mengatur dan mengurus daerahnya serta mampu menggali sumber-sumber keuangan untuk memenuhi kebutuhan pembiayaan pemerintahan dan pembangunan daerahnya.Kewenangan tersebut bertujuan untuk mendorong efisiensi ekonomi, efisiensi pelayanan publik serta meningkatkan kesejahteraan masyarakat.

Berdasarkan perspektif di atas, maka sudah menjadi keharusan bagi pemerintah Kota Jayapura untuk menciptakan efektifitas pengelolaan keuangan daerah. Terjadinya inefektifitas pengelolaan keuangan daerah akan menyebabkan pelaksanaan pembangunan daerah tidak optimal. Berdasarkan kondisi tersebut, maka riset ini menganalisis pengelolaan keuangan daerah di Kota Jayapura dalam era otonomi khusus.

Pertanyaan penelitian adalah: pertama, bagaimana efektifitas pengelolaan keuangan daerah Kota Jayapura sesudah berlakunya otonomi khusus?; kedua, bagaimana kontribusi pendapatan dan pengeluaran daerah Kota Jayapura sesudah 
berlakunya otonomi khusus?; ketiga, bagaimana perencanaan anggaran daerah Kota Jayapura sesudah berlakunya otonomi khusus?

Tujuan penelitian ini adalah menganalisis pengelolaan keuangan daerah setelah berlakunya otonomi khusus Papua, menganalisis kontribusi pendapatan dan pengeluaran daerah Kota Jayapura, serta menganalisis perencanaan pengelolaan keuangan daerah, merumuskan alternatif penggunaan anggaran yang memberikan manfaat optimal kepada masyarakat.

Studi ini menyajikan estimasi tentang pengelolaan keuangan daerah yang dilaksanakan oleh pemerintah Kota Jayapura, khususnya penetapan kebijakan anggaran, mendorong terwujudnya transparansi dan akuntabilitas pengelolaan keuangan daerah serta mengefektifkan pengelolaan keuangan daerah.

\section{METODAPENELITIAN}

\section{Lokasi Penelitian}

Studi ini berlangsung pada kantor Pemerintah Daerah Kota Jayapura. Datadata penting yang berhubungan dengan penelitian akan diperoleh dari kantor dinas pendapatan daerah, badan perencanaan pembangunan daerah Kota Jayapura.

\section{Jenis dan Sumber Data}

Data-data yang digunakan dalam penelitian ini adalah data sekunder yang sudah dipublikasi berupa laporan APBD Kota Jayapura dan laporan pertanggungjawaban Walikota Kota Jayapura (LKPJ) mulai tahun 2002-2009.

\section{Objek Penelitian}

Objek penelitian ini adalah APBD Kota Jayapura yang terdiri dari perencanaan dan realisasi APBD Kota Jayapura mulai tahun 2002 sampai 2009. Kajian berikutnya adalah mengenai efektifitas pengelolaan keuangan daerah, kontribusi pendapatan dan pengeluaran daerah, serta perencanaan pemanfaatan anggaran daerah Kota Jayapura.

\section{Metoda Analisis Data}

Pendekatan yang digunakan yakni terdiri dari dua bagian yakni analisis deskriptif dan analisis kuantitatif. Analisis deskriptif merupakan penelitian terhadap masalah keuangan daerah yang berupa fakta-fakta terkini dari laporan keuangan yang ada. Tujuannya adalah untuk menjawab pertanyaan yang berkaitan dengan current status dari subjek yang diteliti.

Untuk menjawab efektivitas pengelolaan keuangan daerah dengan menggunakan analisis kuantitatif yakni dengan pendekatan rasio. Analisis selanjutnya yakni dengan menggunakan pendekatan induksi dan deduksi. Pendekatan induksi dengan melihat fakta yang ada kemudian melakukan analisis dengan 
dukungan teori yang ada untuk menguraikan dan mengambil kesimpulan dari argumentasi yang diberikan. Sedangkan, pendekatan deduksi melihat dari argumentasi yang diberikan untuk mendapat suatu rumusan dan rancangan program strategi pembangunan daerah Kota Jayapura.

Selanjutnya untuk mendapatkan fakta efektivitas pengelolaan keuangan daerah di Kota Jayapura yakni dengan melakukan analisis terhadap perencanaan dan realisasi laporan keuangan secara horizontal dan vertikal.

\section{Metoda Analisis Horizontal}

Metoda ini menganalisis dengan melakukan perbandingan angka-angka di dalam perkiraan dua laporan yang berbeda. Analisis ini juga bisa dilakukan dengan membandingkan data laporan selama lebih dari satu periode pelaporan sehingga akan menampilkan perubahan yang cukup besar pada perkiraan-perkiraan selama periode tersebut. Terdapat dua metoda dalam analisis horizontal yaitu: comparative analysis dan trend analysis.

a. Comparative Analysis

Analisis ini menghasilkan laporan keuangan selama dua periode atau lebih, peningkatan dan penurunan tiap perkiraan pada pendapatan dan pengeluaran, serta persentase perubahan terhadap periode sebelumnya. Analisis ini terdiri dari: Rasio Efektifitas $=\frac{\text { Realisasi anggaran }}{\text { Rencana anggaran }}$

Rasio Pertumbuhan $=\frac{\text { Realisasi tahun berjalan }- \text { Realisasi tahun lampau }}{\text { Realisasi tahun lampau }}$

b. Analisis Kecenderungan (Indeks Implisit)

Metoda ini akan melakukan perbandingan antara pendapatan dan pengeluaran dalam suatu laporan selama lima tahun. Jika dinyatakan dalam persentase satu periode sebagai periode dasar.

Analisis Kecenderungan $=\frac{\text { Anggaran tahun berjalan }}{\text { Anggaran tahun dasar }}$

\section{Metoda Analisis Vertikal}

Analisis ini juga melakukan perbandingan terhadap pendapatan dan pengeluaran dalam suatu laporan keuangan yang sama sehingga akan menunjukkan persentase suatu perkiraan terhadap perkiraan lainnya. Beberapa alat yang sering digunakan, yakni:

\section{a. Common-Size Financial Statement}

Analisis ini menunjukkan perkiraan-perkiraan dalam laporan keuangan sebagai persentase dari perkiraan dasar (perkiraan dengan nilai 100 persen). Misalnya membandingkan PAD dengan total pengeluaran. Perbandingan antara satu 
anggaran dengan pendapatan dapat diterapkan untuk beberapa rasio yang meliputi: (1) rasio PAD/pengeluaran;(2) rasio dana perimbangan/pendapatan;(3) rasio pengeluaran rutin/pendapatan;(4) rasio pengeluaran pembangunan/pendapatan.

b. Rasio Dua Anggaran

Analisis ini menunjukkan hubungan antara dua perkiraan, diperoleh dengan membagi angka satu perkiraan dengan angka perkiraan lainnya. Beberapa rasio yang dapat dihasilkan dari perbandingan dua mata anggaran ini adalah: (1) rasio PAD/Dana Perimbangan;(2) rasio pengeluaran rutin/riil pengeluaran pembangunan;(3) rasio rutin/pengeluaran pembangunan terserap;(4) rasio pengeluaran pembangunan terserap/riil pengeluaran pembangunan.

\section{Konversi}

Konversi merupakan alat analisis yang mencoba melakukan perpindahan laporan sebelum sebelum otonomi khusus dengan sesudah otonomi khusus. Dari konversi dicoba melakukan perencanaan anggaran keuangan daerah.

\section{Rancangan Strategi}

Dari hasil analisis akan dibuat rancangan strategi keuangan daerah yang meliputi: pendapatan, belanja dan pembiayaan. Tujuannya untuk menghasilkan suatu rumusan strategi pengelolaan keuangan yang dapat diaplikasikan ke dalam pembangunan daerah Kota Jayapura.

\section{KEEFEKTIFAN PENGELOLAAN KEUANGAN DAERAH}

Keefektifan pengelolaan keuangan daerah dapat menggambarkan apakah pengelolaan keuangan daerah dapat menghasilkan manfaat sosial yang maksimal bagi masyarakat atau tidak. Untuk mengukur kefektifan yakni melalui cara:pertama, membandingkan laporan keuangan mulai dari perencanaan dan realisasi untuk setiap tahun anggaran; kedua, menghitung pendapatan dari pendapatan tanpa sisa anggaran yang diterima pada tahun yang bersangkutan dengan mengeluarkan sisa anggaran tahun sebelumnya, karena anggaran tahun sebelumnya tidak termasuk pendapatan; ketiga, memasukkan nilai hasil pengurangan pengeluaran pembangunan riil dengan sisa anggaran pembangunan tahun yang lalu; keempat, menghitung pengeluaran pembangunan yang terserap tahun itu dengan melihat anggaran riil yang terlaksana tahun itu.Keempat komponen dasar perhitungan kefektifan di atas yakni:

\section{Analisis Horizontal}

Pendekatan ini melakukan perbandingan angka-angka dalam perkiraan dua laporan untuk tahun anggaran yang berbeda, serta melalui membandingkan data laporan selama lebih dari satu periode pelaporan sehingga akan menampilkan perubahan yang cukup besar pada perkiraan-perkiraan selama periode tersebut. Ada dua metoda yang terdapat analisis horizontal yaitu pertama comparative analysis. Pada analisis ini akan ditampilkan laporan selama dua periode atau lebih mengenai 
kenaikan dan penurunan tiap perkiraan, serta kedua persentase perubahan terhadap periode sebelumnya.

\section{1) Rasio Keefektifan}

Rasio ini membandingkan mata anggaran yang sama antara rencana dan realisasi, yang menghasilkan data tentang pencapaian target masing-masing mata anggaran. Selain itu angka ini tidak pernah mencapai 100 persen apabila perencanaan yang dibuat berdasarkan potensi yang dimiliki. Bila angka mencapai lebih dari 100 persen menunjukkan sebuah mata anggaran yang direncanakan kurang tepat atau underestimate, atau jauh dari target yang menunjukkan pemerintah overestimate dalam menetapkan anggaran. Dari pemaparan di atas dapat dilihat beberapa hal menyangkut rasio efektifitas dari Kota Jayapura yang rasio efektifitasnya akan disajikan dalam Tabel 1 dan Tabel 2.

\section{a. Rasio Keefektifan PAD}

Upaya pencapaian target PAD di Kota Jayapura terlihat pada Tabel 1 yang menunjukkan bahwa pendapatan daerah dari tahun 2002-2005 mengalami peningkatan. Tahun 2002 yang terendah sebesar Rp229,067 Milyar, sedangkan yang tertinggi tahun 2009 sebesar Rp613,83 Milyar. Selain itu jumlah pengeluaran meningkat dari Rp220,539 Milyar tahun 2002 menjadi Rp279,453 Milyar pada tahun 2005 atau mengalami peningkatan sebesar 26,71 persen. Menurut Enceng dan Purwaningdyah (2008) bahwa efektivitas pengelolaan pajak daerah di Kabupaten Purworejo kurang efektif hanya mencapai 69,47 persen.

Dengan demikian menunjukkan bahwa pendapatan daerah mengalami analisis underestimate tahun 2002-2003 dan tahun 2005 sedangkan tahun 2004 mengalami overestimate. Pengeluaran daerah yang mengalami overestimate setiap tahunnya dengan rata-rata sebesar 96,84 persen. Besarnya pencapaian realisasi di atas target tersebut disebabkan penetapan target yang dilakukan sangat rendah sehingga target mudah tercapai (underestimate). Ini bisa terjadi karena pemerintah daerah selama ini menetapkan target tidak pernah berdasarkan potensi fiskal, akan tetapi berdasarkan perhitungan tahun lalu.

Menurut Dewa (2010) analisis kinerja keuangan daerah pada era otonomi daerah di Provinsi NTB menggambarkan kinerja yang tidak optimal yang ditunjukkan oleh indikator ketergantungan keuangan daerah sangat tinggi terhadap pemerintah pusat. Hadi (2009) menunjukkan kinerja pengelolaan keuangan daerah pemerintah Kota Malang menunjukkan bahwa rasio PAD terhadap TPD Kota Malang relatif besar yaitu berkisar 4,8-7,3 persen lebih besar dari nilai rata-rata nasional sebesar 5 persen. Prakoso (2004) PAD berpengaruh signifikan terhadap belanja daerah di Jawa Tengah dan DIY. 


\section{b. Dana Perimbangan}

Realisasi dana perimbangan Kota Jayapura tahun 2002 sebesar Rp168,635 Milyar atau rasio 101,41 persen. Dana perimbangan tertinggi terjadi pada tahun 2009 yakni Rp567,980 Milyar atau 99,77 persen dan pada tahun yang sama dana perimbangan mengalami overestimate. Pencapaian dana perimbangan yang melebihi 100 persen pada tahun 2002 bisa dianggap sebuah kewajaran sehingga tidak mempunyai angka pembanding untuk melakukan perhitungan. Akan tetapi pada tahun 2003-2008 hal sama juga terjadi sehingga menimbulkan pertanyaan, yang perhitungan target yang underestimate.

Terjadinya underestimate dari target pendapatan mengakibatkan perencanaan pembangunan untuk tahun berjalan lebih rendah dari yang sebenarnya bisa dianggarkan. Akibatnya adalah tingkat perputaran uang dan pembangunan lebih rendah dari yang bisa dilakukan. Dengan kata lain pengelolaan keuangan daerah tidak optimal, karena dilakukan tidak efektif. Menurut Nugraeni (2011) DAU, DAK dan PAD berasosiasi dengan belanja daerah kabupaten/kota di Indonesia. 


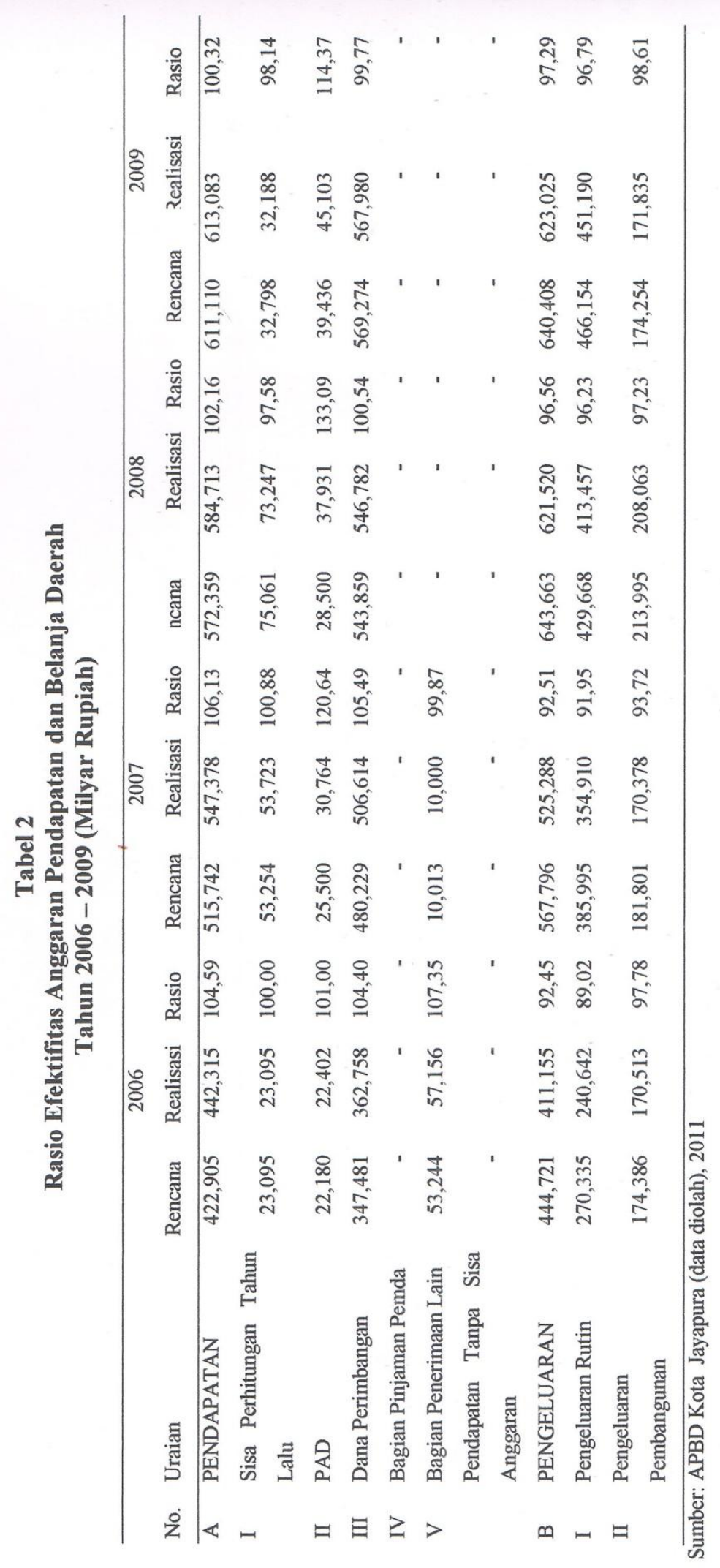


Tabel 1 dan 2 menunjukkan dana perimbangan keuangan setelah otonomi khusus tahun anggaran 2002 menunjukkan bahwa jumlah pendapatan daerah terbesar tahun 2009 sebesar Rp613,083 Milyar, sedangkan yang paling rendah Rp229,067Milyar pada tahun 2002. Pengeluaran (belanja) tertinggi sebesar Rp623,025 Milyartahun 2009 serta diikuti dengan Rp621,520 Milyar pada tahun 2008.

Pencapaian dana perimbangan yang melebihi 100 persen tahun 2002 adalah sebagai sesuatu yang wajar karena merupakan tahun kedua mendapat dana perimbangan dari pusat, sehingga jumlah yang diberikan relatif lebih besar dan juga belum dilakukan perbandingan dengan tahun sebelumnya untuk melakukan perhitungan.

c. Pengeluaran Rutin

Realisasi pengeluaran rutin Kota Jayapura periode tahun 2002-2009 tidak mencapai 100 persen dan hanya dibawah dari 97,83 persen serta yang terendah pada tahun 2006 sebesar 89,02 persen, sehingga dapat dikatakan bahwa pengeluaran rutin yang terdapat pada APBD Kota Jayapura tidak mencapai target atau dengan kata lain sangat mendominasi dari total pengeluaran pembangunan.

d. Pengeluaran Pembangunan

Berdasarkan waktu pengamatan, tingkat pencapaian belanja pembangunan di Kota Jayapura pada umumnya sangat jauh dari target. Yang paling rendah terjadi pada tahun 2005 hanya 54,71 persen. Fenomena tersebut menunjukkan bahwa pemerintah daerah tidak mampu memanfaatkan dana tersebut untuk melaksanakan pembangunan.

2) Rasio Pertumbuhan.

Berdasarkan Tabel 3, terjadi fluktuasi dari total anggaran pada saat Otonomi Khusus. Sisa perhitungan yang tertinggi terjadi pada tahun 2006 sebesar 892,05 persen serta 2007 sebesar 132,62 persen, sedangkan terendah sebesar $-78,77$ persen tahun 2005 diikuti tahun 2009 sebesar $-56,06$ persen. Persentase pendapatan daerah yang tertinggi yakni pada tahun 2006 sebesar 46,98 persen.

Tabel 3 menunjukkan jumlah pendapatan dan PAD tertinggi adalah sebesar 46,98 persen tahun 2006, diikuti tahun 2007 sebesar 23,75 persen. Sedangkan jumlah dana perimbangan tertinggi sebesar 49,55 persen tahun 2006, diikuti tahun 2007 sebesar 39,66 persen serta terendah sebesar -0,60 tahun 2004. Jumlah pengeluaran tertinggi sebesar 47,13 persen tahun 2006 dan terendah sebesar 0,24 persen tahun 2009. Kondisi tersebut disebabkan oleh semakin banyaknya pemekaran wilayah di Provinsi Papua, sehingga akan berpengaruh terhadap ketersediaan jumlah dana perimbangan keuangan yang didistribusi untuk daerah Kota Jayapura semakin kecil. 
Tabel 3

Tingkat Pertumbuhan Realisasi Anggaran Kota Jayapura Setelah Otonomi Khusus Tahun 2002-2009

\begin{tabular}{clrrrrrrr}
\hline No. & \multicolumn{1}{c}{ Uraian } & $\mathbf{2 0 0 3}$ & $\mathbf{2 0 0 4}$ & $\mathbf{2 0 0 5}$ & $\mathbf{2 0 0 6}$ & $\mathbf{2 0 0 7}$ & $\mathbf{2 0 0 8}$ & $\mathbf{2 0 0 9}$ \\
\hline A & PENDAPATAN & $18,61 \%$ & $-4,71 \%$ & $16,24 \%$ & $46,98 \%$ & $23,75 \%$ & $6,82 \%$ & $4,85 \%$ \\
I & Sisa Perhitungan & $43,05 \%$ & $28,58 \%$ & - & $892,05 \%$ & $132,62 \%$ & $36,34 \%$ & - \\
& & & & $78,77 \%$ & & & & $56,06 \%$ \\
II & PAD & $30,78 \%$ & $14,08 \%$ & $26,60 \%$ & $6,07 \%$ & $37,33 \%$ & $23,30 \%$ & $18,91 \%$ \\
III & Dana Perimbangan & $19,14 \%$ & $-0,60 \%$ & $21,47 \%$ & $49,55 \%$ & $39,66 \%$ & $7,93 \%$ & $3,88 \%$ \\
IV & Bagian Pinjaman & - & - & - & - & - & - & - \\
& Pemda & & & & & & & \\
V & Bagian Penerimaan & $10,05 \%$ & - & - & $53,46 \%$ & $-82,50 \%$ & - & - \\
& lain & & $10,73 \%$ & $12,42 \%$ & & & & \\
B & PENGELUARAN & $18,22 \%$ & $2,23 \%$ & $4,85 \%$ & $47,13 \%$ & $27,76 \%$ & $18,32 \%$ & $0,24 \%$ \\
1 & Pengeluaran Rutin & $40,11 \%$ & $14,87 \%$ & $6,23 \%$ & $7,08 \%$ & $47,48 \%$ & $16,50 \%$ & $9,13 \%$ \\
2 & Pengeluaran Pemb. & $14,07 \%$ & - & $-0,48 \%$ & $211,64 \%$ & $-0,08 \%$ & $22,12 \%$ & - \\
& & & $28,18 \%$ & & & & & $17,41 \%$
\end{tabular}

Sumber: APBD Kota Jayapura (data diolah), 2011.

a. Pendapatan Asli Daerah (PAD)

PAD Kota Jayapura tertinggi terjadi pada tahun 2009 yakni sebesar Rp39,436 Milyar sedangkan yang terendah sebesar Rp9,902 Milyar pada tahun 2002. Kenaikan tersebut disebabkan semakin banyaknya jumlah badan usaha daerah yang menghasilkan pendapatan, potensi-potensi pendapatan dari berbagai sektor sudah diintensifkan serta ekstensifikasi pendapatan baik melalui pajak maupun retribusi daerah.

b. Dana Perimbangan

Dana perimbangan merupakan bagian dana yang ditransfer pusat ke daerah. Jumlah dana perimbangan sangat mendominasi anggaran daerah yakni dengan jumlah Rp569,274 Milyar tahun 2009 menurun menjadi Rp543,859 Milyar tahun 2008. Dengan demikian maka tidak dapat dipastikan jumlah dana perimbangan keuangan pada masa mendatang tetap menjadi primadona dalam anggaran daerah.

c. Pengeluaran Rutin (Belanja Aparatur)

Anggaran ini setiap tahunnya terus mengalami peningkatan diikuti dengan semakin besarnya tanggung jawab yang diemban oleh daerah. Pertumbuhan yang sangat besar terjadi tahun 2008 sebesar Rp429,668Milyar mengalami peningkatan sebesar Rp36,486 Milyar pada tahun 2009. Hal tersebut mencerminkan bahwa pengelolaan keuangan daerah Kota Jayapura tidak efisien. 


\section{d. Pengeluaran Pembangunan (Belanja Publik)}

Peningkatan pengeluaran pembangunan terjadi pada tahun 2008 dan 2009. Tahun 2008 sebesar Rp213,995 Milyar diikuti tahun 2009 sebesar Rp174,254 Milyar. Kondisi ini menunjukkan bahwa komitmen pemerintah daerah untuk mempercepat pembangunan daerah sangat minim.

Pada Gambar 1 terlihat bahwa angka riil pengeluaran pembangunan sangat fluktuatif. Pada tahun 2006 riil pengeluaran pembangunan mengalami kenaikan menjadi Rp268,115 Milyar namun pada tahun 2009 riil pengeluaran pembangunan kembali mengalami penurunan masing-masing sebesar Rp346,565 Milyar.

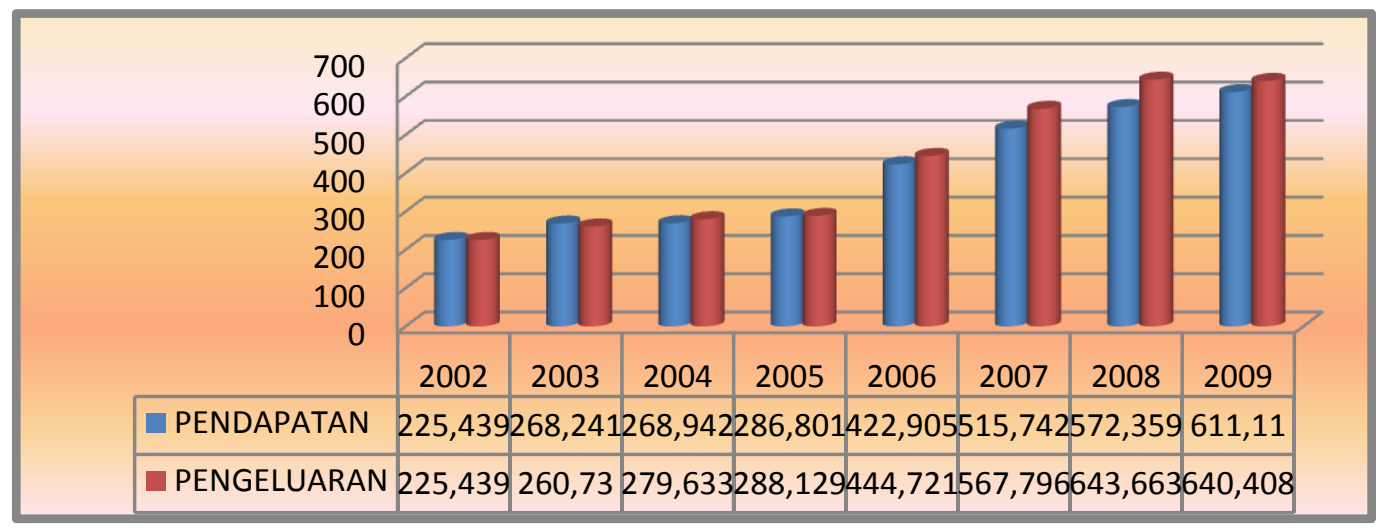

\section{Gambar 1 \\ APBD Kota Jayapura Berdasarkan Rencana Riil Pengeluaran Pembangunan (dalam Milyar Rupiah)}

3). Analisis Kecenderungan

Analisis kecenderungan yang dimaksudkan ini adalah mengamati perkembangan time series data laporan, yaitu perkiraan-perkiraan dalam suatu laporan tertentu selama delapan tahun diberlakukannya otonomi khusus mulai tahun 2002-2009.

Pada Tabel 4, trend kenaikan APBD Kota Jayapura periode 2002-2009 mengalami peningkatan. Peningkatan tertinggi terjadi pada tahun 2005-2006 yakni sebesar Rp141,374 Milyar diikuti tahun 2006-2007 sebesar Rp105,063 Milyar. Sedangkan peningkatan rata-rata sebesar Rp54,859 Milyar setiap tahunnya. Peningkatan pendapatan daerah tersebut disebabkan oleh semakin besarnya pajak yang dihasilkan oleh PT Freeport Indonesia terhadap APBN, sehingga dengan sendirinya dana yang ditransfer pusat ke Papua juga meningkat. 
Tabel 4

Trend Kenaikan APBD Kota Jayapura Tahun 2002 s/d 2009 (Milyar Rupiah)

\begin{tabular}{|c|c|c|c|c|c|c|c|c|c|}
\hline No. & Uraian & 2002 & 2003 & 2004 & 2005 & 2006 & 2007 & 2008 & 2009 \\
\hline 1 & Realisasi PAD & 11,182 & 14,624 & 16,683 & 21,121 & 22,402 & 30,764 & 37,931 & 45,103 \\
\hline 2 & $\begin{array}{l}\text { Realisasi } \\
\text { Perimbangan }\end{array}$ & 168,635 & 200,905 & 199,691 & 242,573 & 362,758 & 506,614 & 546,782 & 567,980 \\
\hline 3 & Jumlah Pendapatan & 229,067 & 271,695 & 258,902 & 300,941 & 442,315 & 547,378 & 584,713 & 613,083 \\
\hline 4 & $\begin{array}{l}\text { Realisasi } \\
\text { Pengeluaran Rutin }\end{array}$ & 131,451 & 184,173 & 211,557 & 224,738 & 240,642 & 354,910 & 413,457 & 451,190 \\
\hline 5 & $\begin{array}{l}\text { Riil Pengeluaran } \\
\text { Pembangunan }\end{array}$ & 89,088 & 76,557 & 54,981 & 54,715 & 170,513 & 170,378 & 208,063 & 171,835 \\
\hline 6 & $\begin{array}{l}\text { Pengeluaran Pemb. } \\
\text { Terserap }\end{array}$ & 83,127 & 68,030 & 44,035 & 52,387 & 147,418 & 116,655 & 134,816 & 139,647 \\
\hline
\end{tabular}

a. Pendapatan Asli Daerah (PAD)

Kecenderungan perkembangan PAD Kota Jayapura selama periode penelitian yakni tahun 2002-2009 rata-rata mengalami kenaikan setiap tahunnya. Artinya bahwa pemerintah daerah Kota Jayapura bisa menggali sumber-sumber pendapatan dari daerahnya sendiri sebagai sumber keuangan daerah.

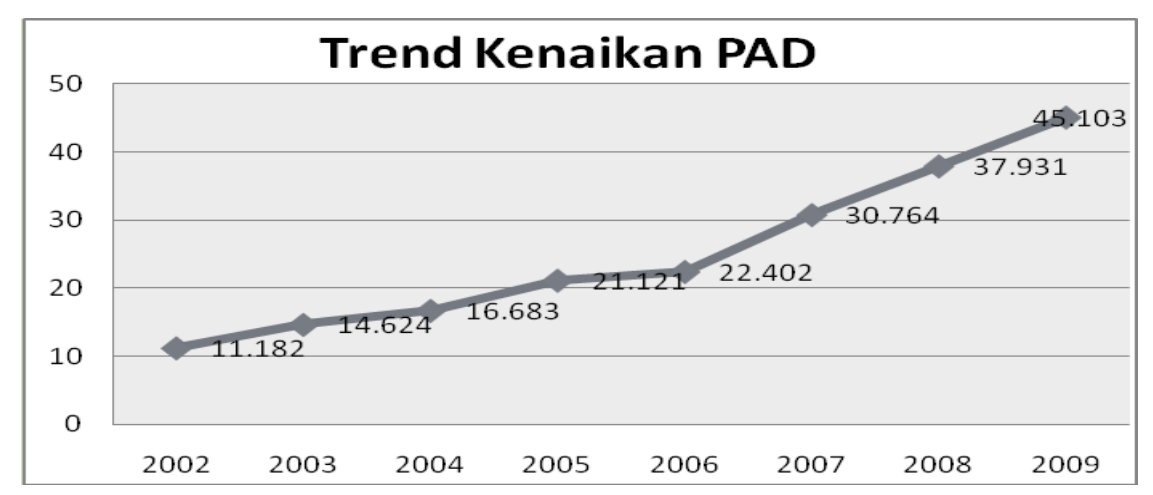

Gambar 2

Kecenderungan PAD

b. Dana Perimbangan

Berdasarkan trend dana perimbangan tahun 2006 distribusi dana perimbangan mengalami peningkatan yang besar. Sedangkan tahun 2007-2009 mengalami penurunan. Hal ini menunjukkan bahwa Kota Jayapura sudah mulai mampu memanfaatkan dan mengubah dan mengelola kekayaan sumber daya alam yang ada menjadi sumber pendapatan. Hal itu sejalan dengan pendapat Astuti dan Joko (2005) ada daerah yang dianugerahi kekayaan alam yang sangat melimpah seperti di Riau, Aceh, Kalimantan Timur dan Papua yakni berupa minyak bumi dan gas 
alam (migas), pertambangan dan kehutanan. Ada juga daerah yang sebenarnya tidak memiliki kekayaan alam yang besar namun karena struktur perekonomian mereka telah tertata dengan baik maka potensi pajak dapat dioptimalkan sehingga daerah tersebut menjadi kaya.

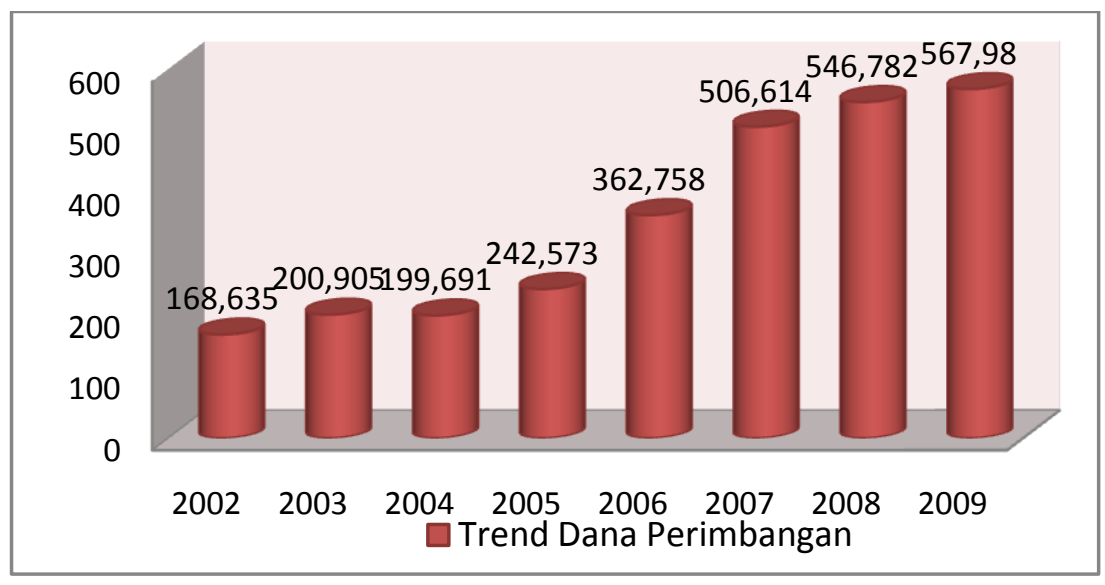

Gambar 3

Trend Dana Perimbangan

c. Pengeluaran Rutin (Belanja Aparatur)

Peningkatan trendpengeluaran rutin terjadi pada tahun 2002-2009. Peningkatan pengeluaran tersebut rata-rata sebesar Rp45,677 Milyar/tahun. Peningkatan pengeluaran tersebut disebabkan gaji pegawai negeri sipil daerah dibayar oleh pemerintah daerah setempat ditambah lagi dengan tunjangan kemahalan dan tunjangan jabatan yang sangat besar sehingga sangat memberatkan APBD setempat.

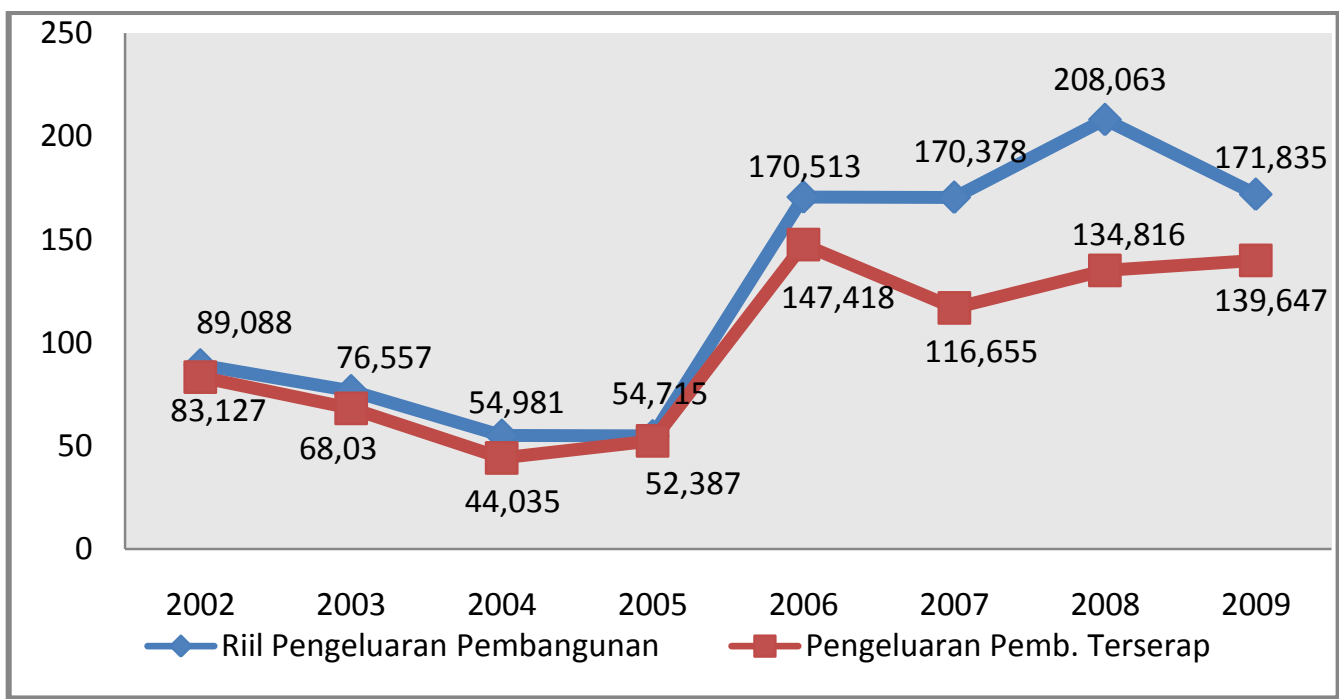

Gambar 4

Trend Pengeluaran Rutin 
d. Riil Pengeluaran Pembangunan

Trendriil pengeluaran pembangunan menunjukkan pada tahun 2002-2004 mengalami penurunan, tahun 2005-2006 meningkat rata-rata sebesar Rp99,903 Milyar sedangkan 2007-2009 juga mengalami peningkatan sebesar Rp11,496 Milyar.Kondisi tersebut menunjukkan bahwa ketidakmampuan untuk mempercepat pembangunan daerah sehingga dapat mengurangi ketertinggalan dengan daerah lainnya di luar Papua.

e. Pengeluaran Pembangunan Terserap

Trend pengeluaran pembangunan terserap menggambarkan terjadinya fluktuasi naik turunnya pengeluaran pembangunan terserap tidak jauh berbeda dengan kondisi riil pengeluaran pembangunan yang fluktuatif. Pengeluaran tahun 2004 sebesar Rp44,035 Milyar sebagai pengeluaran pembangunan terserap terendah, sedangkan tertinggi yakni sebesar Rp139,647 Milyar tahun 2009.

\section{Analisis Vertikal}

Analisis vertikal merupakan metoda analisis yang membandingkan perkiraanperkiraan dalam suatu laporan keuangan yang sama sehingga menunjukkan persentase suatu perkiraan terhadap perkiraan lainnya.

\section{1) Common-Size Financial Statement}

Adalah suatu analisis yang menunjukkan perkiraan-perkiraan dalam laporan keuangan sebagai persentase dari perkiraan dasar (perkiraan dengan nilai 100 persen). Pada analisis ini perbandingan dilakukan dengan total pendapatan.

a. Perbandingan PAD dengan Pendapatan Daerah

Pada era Otonomi Khusus kontribusi PAD terhadap pendapatan daerah mengalami kenaikan setiap tahunnya, sedangkan pendapatan bagi hasil daerah jumlahnya besar, akan tetapi kontribusinya terhadap pendapatan daerah terus mengalami kenaikan selama empat tahun terakhir. Jadi bila dibandingkan antara PAD dan pendapatan bagi hasil daerah maka terlihat jelas bahwa persentase perbandingan pendapatan bagi hasil daerah dengan pendapatan daerah mencapai angka yang sangat besar. Kondisi ini menggambarkan bahwa tingkat ketergantungan daerah Kota Jayapura untuk melakukan pembiayaan pembangunan dari dana bagi hasil sangat besar, karena disebabkan adanya peningkatan pendapatan asli daerah Kota Jayapura. Sedangkan menurut Rudi (2011) menggambarkan bahwa tingkat kemandirian keuangan kabupaten/kota di Sumatera Selatan menunjukkan terjadinya penurunan kategori keuangan yang dihubungkan dengan rasio keuangan kecukupan diri (RKKD) di bawah 20 persen. Hal ini berarti bahwa kabupaten/kota masih mengalami ketergantungan penuh terhadap pemerintah pusat.

b. Perbandingan Dana Perimbangan dengan Pendapatan 
Kontribusi dana perimbangan terhadap pendapatan daerah Kota Jayapura sangat besar pada era otonomi khusus. Jumlah dana perimbangan/pendapatan meningkat mulai tahun 2002-2008. Tahun 2002 sebesar 73,63 persen meningkat hingga mencapai 93,51 persen sampai tahun 2008. Kondisi tersebut menunjukkan semakin besarnya ketergantungan daerah Kota Jayapura terhadap sumber pembiayaan pembangunan dari dana bagi hasil.

c. Perbandingan Pengeluaran Rutin dengan Pendapatan

Pengeluaran rutin mengalami kenaikan pada tahun 2002-2004, sedangkan tahun 2005-2006 mengalami penurunan, serta mengalami peningkatan kembali mulai tahun 2007-2009. Pada saat otonomi sebagian besar pendapatan tidak lagi digunakan untuk belanja aparatur. Namun demikian perkembangan belanja aparatur terus mengalami kenaikan yang cukup berarti dari tahun ke tahun, yang mengindikasikan semakin besarnya kebutuhan biaya pembangunan daerah.

d. Perbandingan Riil Pengeluaran Pembangunan dengan Pendapatan

Tahun anggaran 2003-2005, rasio riil pengeluaran pembangunan dengan pendapatan sebesar 18,18 persen, angka rasio di bawah 50 persen. Dengan demikian secara tidak langsung terjadi transfer payment dari masyarakat untuk pelayanan aparatur negara Kota Jayapura pada awal era otonomi khusus. Selanjutnya rasio riil pengeluaran pembangunan dengan pendapatan mengalami fluktuasi dari tahun 2006-2009 hal tersebut menunjukkan pengeluaran pemerintah difokuskan untuk membangunan masyarakat.

e. Perbandingan Dana Perimbangan dengan Pendapatan

Kontribusi dana perimbangan terhadap pendapatan daerah Kota Jayapura sangat besar pada era Otonomi Khusus. Jumlah dana perimbangan/pendapatan meningkat mulai tahun 2002-2008. Tahun 2002 sebesar 73,63 persen meningkat hingga mencapai 93,51 persen sampai tahun 2008. Kondisi tersebut menunjukkan semakin besarnya ketergantungan daerah Kota Jayapura terhadap sumber pembiayaan pembangunan dari dana bagi hasil.

f. Perbandingan Pengeluaran Rutin dengan Pendapatan

Pengeluaran rutin mengalami kenaikan pada tahun 2002-2004, sedangkan tahun 2005-2006 mengalami penurunan, serta mengalami peningkatan kembali mulai tahun 2007-2009. Pada saat otonomi sebagian besar pendapatan tidak lagi digunakan untuk belanja aparatur. Namun demikian perkembangan belanja aparatur terus mengalami kenaikan yang cukup berarti dari tahun ke tahun, yang mengindikasikan semakin besarnya kebutuhan biaya pembangunan daerah.

g. Perbandingan Riil Pengeluaran Pembangunan dengan Pendapatan

Tahun anggaran 2003-2005, rasio riil pengeluaran pembangunan dengan pendapatan sebesar 18,18 persen, angka rasio di bawah 50 persen. Dengan demikian secara tidak langsung terjadi transfer payment dari masyarakat untuk pelayanan aparatur negara Kota Jayapura pada awal era otonomi khusus. Selanjutnya rasio riil pengeluaran pembangunan dengan pendapatan mengalami 
fluktuasi dari tahun 2006-2009 hal tersebut menunjukkan pengeluaran pemerintah difokuskan untuk membangunan masyarakat.

h. Perbandingan Pengeluaran Pembangunan Terserap dengan Pendapatan

Tahun 2003 dana terserap adalah 25,04 persen, sedangkan tahun 2009 mencapai 22,78 persen.Kondisi tersebut menunjukkan rendahnya penyerapan dana pembangunan, selain itu anggaran yang direncanakan dapat terpakai semuanya, dimana sisa anggaran tahun berjalan tersebut akhirnya menjadi proyek luncuran untuk tahun berikutnya. Dengan demikian efektifitas pengelolaan keuangan daerah Kota Jayapura masih rendah. Kondisi yang sama juga terjadi di seluruh kabupaten Jayapura dan Provinsi Papua secara umum (Halomoan et al., 2012).

2) Rasio Perbandingan Dua Anggaran

Perbandingan dua anggaran merupakan suatu metoda untuk membandingkan dua pos anggaran yang berbeda.

a. Rasio PAD dengan dana Perimbangan.

Selisih penerimaan PAD Kota Jayapura dengan dana perimbangan menunjukkan angka yang sangat besar yang ditandai dengan kecilnya rasio PAD dengan dana perimbangan. Pada tahun 2002-2005, rasio penerimaan PAD dengan dana perimbangan yakni sekitar 6,63-8,71 persen. Selanjutnya rasio penerimaan PAD dengan dana perimbangan mengalami kenaikan selama tahun 2005-2009 hingga mencapai 7,94 persen. Menurut Haris dan Nasikh (2013) bahwa derajat desentralisasi fiskal keuangan daerah sebelum dan sesudah otonomi daerah di kota Malang masih belum mandiri. Artinya prosentase dari PAD terhadap total penerimaan daerah masih relatif kecil dibandingkan dengan dana perimbanan dari pemerintah pusat.

b. Rasio Pengeluaran Rutin dengan Riil Pengeluaran Pembangunan.

Rasio pengeluaran rutin dengan riil pengeluaran pembangunan Kota Jayapura terus meningkat mulai tahun 2003-2005 dengan angka mencapai 410,74 persen, tetapi pada tahun 2006 dan 2007 rasio mengalami penurunan. Kondisi tersebut disebabkan oleh kenaikan pengeluaran rutin bisa diimbangi oleh kenaikan riil pengeluaran pembangunan.

c. Rasio Pengeluaran Rutin dengan Pengeluaran Pembangunan Terserap.

Rasio pengeluaran rutin dengan pengeluaran pembangunan terserap meningkat dari tahun 2002-2005, selanjutnya angka rasio menurun tajam pada tahun 2006. Hal ini sejalan dengan naik turunnya nilai pengeluaran pembangunan terserap walaupun pengeluaran rutin terus mengalami kenaikan selama tiga tahun terakhir.

d. Rasio Pengeluaran Pembangunan Terserap dengan Riil Pengeluaran Pembangunan.

Rasio perbandingan pengeluaran pembangunan terserap dengan riil pengeluaran pembangunan tahun 2003 adalah 88,86 persen, sedangkan tahun 2005 menjadi 95,75 persen. Tahun 2007 menurun hingga mencapai 68,41 persen. Dengan semakin kecilnya rasio pengeluaran pembangunan terserap dengan riil pengeluaran pembangunan pada tahun-tahun terakhir mengindikasikan bahwa 
pemerintah pemerintah daerah Kota Jayapura belum memiliki kemampuan untuk mengelola anggaran terutama untuk kegiatan pembangunan, sehingga dana yang tersedia belum dapat terealisasi dengan baik. 


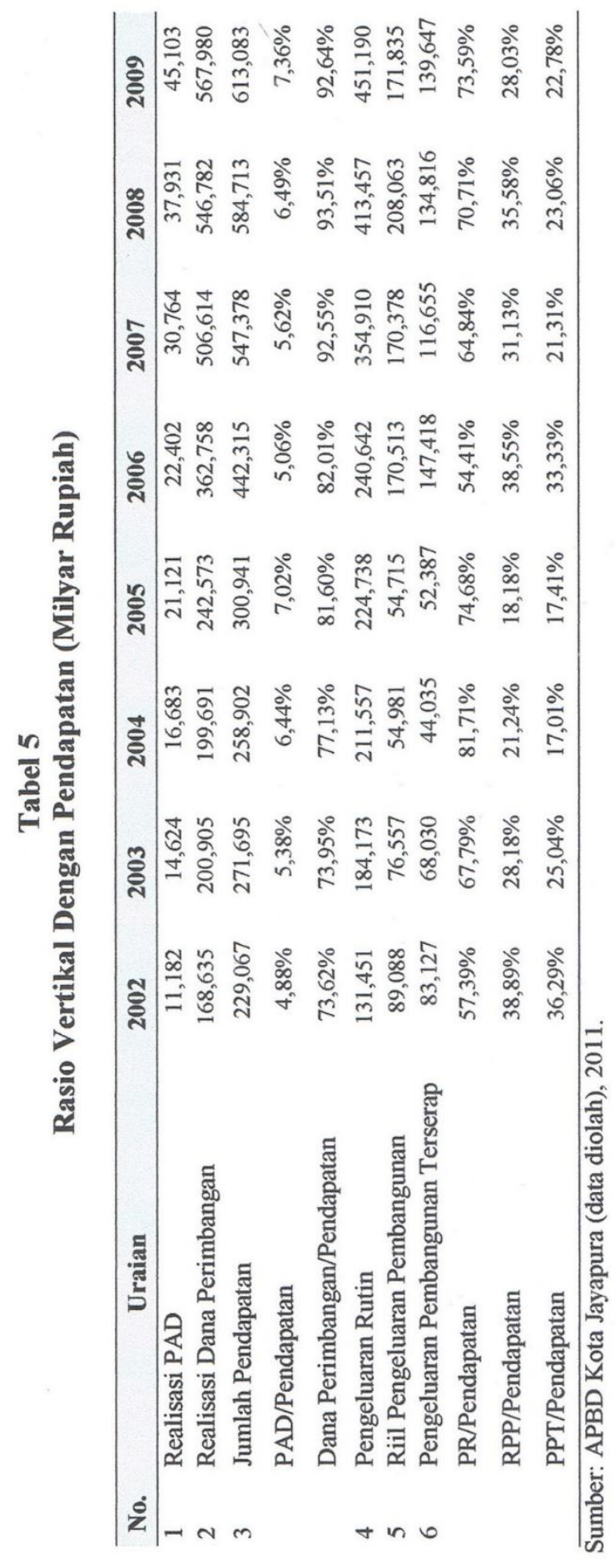




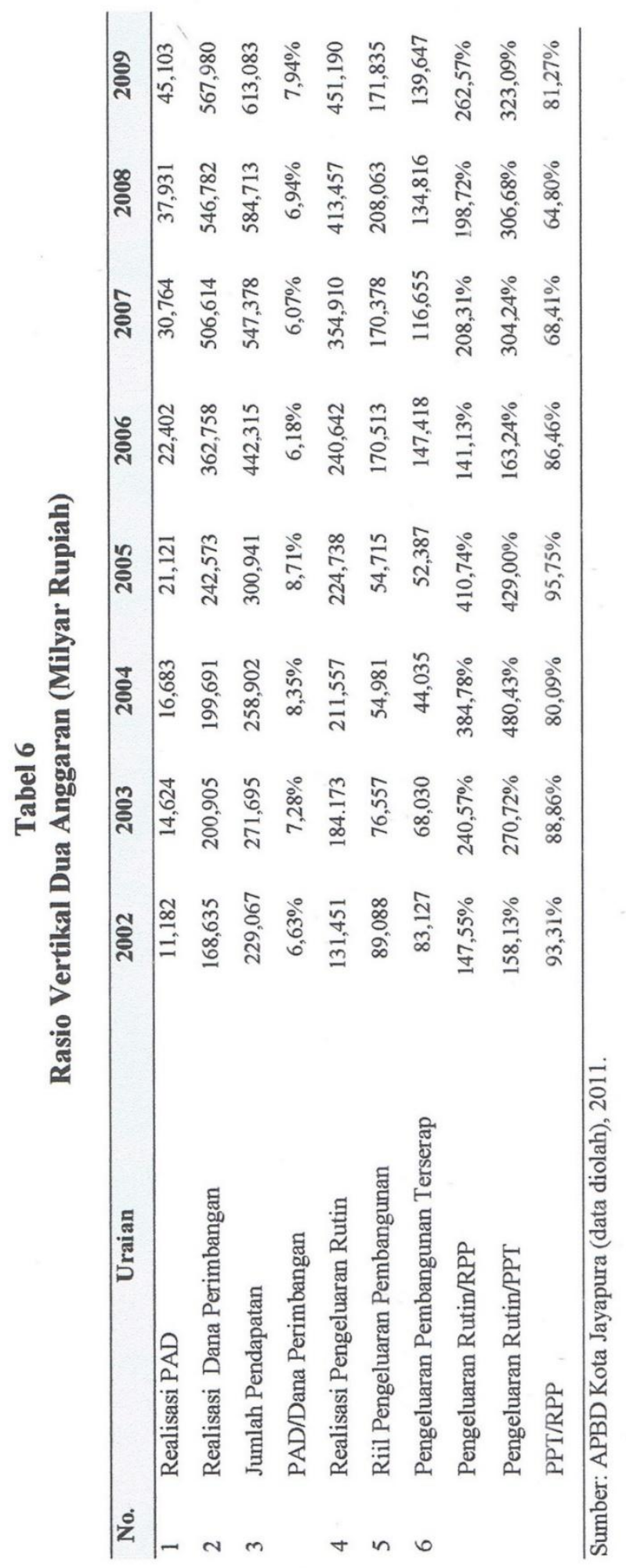




\section{Analisis Perencanaan Keuangan Daerah}

Perencanaan keuangan daerah diera otonomi khusus merujuk kepada Peraturan Pemerintah 108 tahun 2000 tentang Penerimaan Asli Daerah (PAD). Dalam Peraturan Pemerintah disebutkan kewajiban pemerintah daerah membuat rencana strategi pembangunan daerah. Rencana strategi ini disahkan dalam bentuk peraturan daerah.

Dari sisi historis anggaran perencanaan yaitu dengan melihat perkembangan keuangan daerah masa lampau untuk perencanaan tahun ke mendatang dan juga bisa dilihat dengan memperbandingkan setiap mata anggaran berdasarkan analisisrasio yang telah dibahas di atas, atau berdasarkan prioritas pengalokasian anggaran dalam pembahasan masalah perencanaan keuangan ini.

Analisis keuangan bisa digunakan dari berbagai aspek, tergantung sejauh mana kedalaman pembahasannya. Oleh karena itu analisis keuangan juga bisa menjadi alat dalam membuat suatu keputusan untuk masa mendatang yaitu dengan data yang ada untuk melakukan proyeksi. Dengan data historis yang dimiliki bisa melihat trend, rasio, perbandingan antara anggaran dan lain-lain. Meskipun demikian kita juga jangan terjebak dengan cara berpikir incremental dalam melakukan perencanaan keuangan.

Gambaran tentang kondisi aktual pengelolaan PAD di Kota Jayapura (Tabel 7) yaitu: pertama, terjadi underestimated terhadap PAD karena penetapan tidak berdasarkan potensi; kedua, rendahnya kontribusi PAD terhadap pendapatan; ketiga, mempunyai trend yang fluktuatif sehingga cenderung tidak dapat diprediksi; keempat, rasio yang rendah terhadap dana perimbangan.

Merujuk kepada semua indikator di atas, maka alternatif perencanaan yang dianggap mampu mengoptimalkan PAD Kota Jayapura adalah: pertama, mendata kembali PAD yang berdasarkan pada potensi yang dimiliki; kedua, memisahkan PAD yang potensial dengan yang kurang potensial. Apabila ada PAD yang tidak potensiAl dan memerlukan biaya besar dalam pemungutan, maka bisa saja salah satu pungutan itu dihapuskan, sehingga tidak memberatkan masyarakat. Sebaliknya PAD yang potensial tapi belum optimal penagihannya, maka ini bisa menjadi fokus pemungutan; ketiga, Memisahkan PAD mana yang predictable dan unpredictable, sehingga memudahkan untuk melakukan proyeksi terhadap PAD.

Mengenai dana perimbangan,berdasarkan analisis rasio dan kecenderungan dana perimbangan terdapat dua kondisi aktual yaitu (1) terjadi peningkatan yang sangat besar dari sebelum otonomi khusus walaupun dengan jumlah yang kecil dan (2) kontribusi yang sangat tinggi terhadap pendapatan daerah Kota Jayapura yakni di atas 90 persen setelah Otonomi Khusus. Sedangkan menurut Askam (2008) bahwa manajemen pengeluaran pemerintah daerah khususnya dalam hal alokasi belanja modal pemerintah daerah kabupaten/kota di Indonesia sangat tergantung pada alokasi dana dari pemerintah pusat, baik DAU maupun DAK dan PAD serta PDRB.

Pengeluaran rutin,dalam pembahasan sebelumnya menunjukkan terdapat beberapa indikator perkembangan pengeluaran rutin yakni: pertama, terjadi 
peningkatan yang cukup tajam pada belanja ini; kedua, persentase terhadap pendapatan mengalami kenaikan setelah otonomi khusus yang sangat membebani anggaran daerah; ketiga, rasio yang sangat tinggi dibandingkan anggaran pembangunan.Dengan mencermati kondisi tersebut di atas, pemerintah daerah Kota Jayapura dapat melakukan beberapa perencanaan keuangan daerah seperti: pertama, membuat satuan anggaran belanja yang benar sehingga mempunyai ukuran yang jelas dalam menetapkan besarannya; kedua, melakukan efisiensi dengan pengawasan adanya pemborosan dan kebocoran yang selama ini dikenal sangat besar pada pengeluaran ini; ketiga, membuat prioritas kerja yang jelas.

Berikutnya adalah pengeluaran pembangunan. Kondisi pengeluaran mengalami beberapa hal: pertama, terjadi kecenderungan pengeluaran pembangunan yang terus menurun pada masa otonomi khusus; kedua, jumlah anggaran pembangunan yang terserap setiap tahunnya sangat kecil, walaupun angka ini terus mengalami kenaikan.

Guna memecahkan permasalahan di atas, maka langkah perencanaan yang bisa dilakukan pemerintah daerah adalah: (1) melakukan prioritas dan komitmen yang jelas terhadap pembangunan daerah; (2) dibutuhkan keberpihakan yang nyata oleh pemerintah daerah terhadap masyarakat; (3) evaluasi program pembangunan secara nyata dan terus menerus; (4) melakukan efektifitas pelaksanaan program pembangunan pembangunan daerah; (5) keterlibatan peran serta masyarakat dalam pelaksanaan program dan pengawasan program, sehingga tingkat keberhasilan program semakin baik.

\section{Konversi Anggaran Setelah Otonomi Khusus di Kota Jayapura}

Konversi adalah salah satu cara yang dilakukan dengan memindahkan laporan keuangan sebelum otonomi dan sesudah otonomi. Walaupun konversi ini tidak selalu tepat, karena input dan proses penyusunan anggaran serta satuan anggaran belanja yang ditetapkan, namun secara umum ini sudah mendekati, dengan asumsipengeluaran rutin sama dengan belanja aparatur dan belanja pembangunan sama dengan belanja publik.

Tabel 7

Konversi Anggaran Berdasarkan Perencanaan Pendapatan (MilyarRupiah)

\begin{tabular}{lllllllll}
\hline Uraian & 2002 & 2003 & 2004 & 2005 & 2006 & 2007 & 2008 & 2009 \\
\hline JumlahPendapatan & 229,067 & 271,695 & 258,902 & 300,941 & 442,315 & 547,378 & 584,713 & 613,083 \\
Belanja Aparatur & 131,451 & 184,173 & 211,557 & 224,738 & 240,642 & 354,910 & 413,457 & 451,190 \\
Belanja Publik & 89,088 & 76,557 & 54,981 & 54,715 & 170,513 & 170,378 & 208,063 & 171,835 \\
Jumlah Belanja & 220,539 & 260,730 & 266,538 & 279,453 & 411,155 & 525,288 & 621,520 & 623,025 \\
Surplus/Defisit & 8,528 & 10,965 & $-7,636$ & 21,488 & 31,160 & 22,090 & $-36,807$ & $-9,942$ \\
\hline \multicolumn{7}{l}{ Sumber: APBD Kota Jayapura (data diolah), 2011. }
\end{tabular}


Pendekatan-pendekatan konversi terdiri dari: pertama, konversi berdasarkan rencana pendapatan;kedua, konversi berdasarkan realisasi pendapatan. Seperti yang disebutkan dalam analisis sebelumnya bahwa pendapatan sering direncanakan dengan underestimated, maka itu perlu dibuat dua konversi tersebut pada Tabel 7 dan Tabel 8.

Pada Tabel konversi anggaran berdasarkan rencana pendapatan menunjukkan bahwa kondisi keuangan Pemerintah Kota Jayapura mengalami defisit. Tahun Anggaran 2002 dan 2003 kondisi keuangan menunjukkan keseimbangan antara pendapatan dan pengeluaran, sedangkan tahun 2004-2009 terjadi defisit keuangan. Angka defisit anggaran yang tertinggi sebesar Rp71,304 Milyar tahun 2008 dan terendah tahun 2005 sebesar Rp-1,328 Milyar. Terjadinya pembengkakan pengeluaran pada tahun-tahun tersebut disebabkan oleh terjadinya pemekaran wilayah Kota Jayapura menjadi dua wilayah pemerintah yakni Kota Jayapura dengan Kabupaten Keerom, serta biaya-biaya perbaikan kembali sarana infrastruktur daerah yang rusak akibat banjir/longsor yang terjadi pada tahun 2007/2008.

Tabel 8

Konversi Anggaran Berdasarkan Realisasi Pendapatan (Milyar Rupiah)

\begin{tabular}{lllllllll}
\hline Uraian & 2002 & 2003 & 2004 & 2005 & 2006 & 2007 & 2008 & 2009 \\
\hline Jumlah & 229,067 & 271,695 & 258,902 & 300,941 & 442,315 & 547,378 & 584,713 & 613,083 \\
Pendapatan & & & & & & & & \\
Belanja Aparatur & 131,451 & 184,173 & 211,557 & 224,738 & 240,642 & 354,910 & 413,457 & 451,190 \\
Belanja Publik & 89,088 & 76,557 & 54,981 & 54,715 & 170,513 & 170,378 & 208,063 & 171,835 \\
Jumlah Belanja & 220,539 & 260,730 & 266,538 & 279,453 & 411,155 & 525,288 & 621,520 & 623,025 \\
Surplus/Defisit & 8,528 & 10,965 & $-7,636$ & 21,488 & 31,160 & 22,090 & $-36,807$ & $-9,942$
\end{tabular}

Sumber: APBD Kota Jayapura (data diolah), 2011

Pada konversi pertama yang terjadi adalah defisit anggaran, serta pada tahun 2004, 2008 dan 2009 mengalami defisit anggaran, sedangkan konversi kedua terjadi anggaran surplus. Apabila perhitungan pendapatan dibuat dengan tepat maka akan terjadi surplus anggaran. Surplus anggarannya yaitu: (1) tahun 2002 surplus anggaran sebanyak Rp8,528 Milyar; (2) tahun 2003 surplus anggaran sebanyak Rp10,965 Milyar rupiah; (3) tahun 2005 surplus anggaran sebanyak Rp21,488 Milyar; (4) tahun 2006 surplus anggaran sebanyak Rp31,160 Milyar; (5) tahun 2007 surplus anggaran sebanyak Rp22,090 Milyar.

Bila konversi yang kedua digunakan dalam memperkuat analisis terdahulu, hal itu menunjukkan bahwa pemerintah daerah tidak efektif dalam mengelola keuangan daerah. Sedangkan pada sisi lain terciptanya surplus anggaran selama otonomi khusus yakni menunjukkan bahwa: pertama, terdapat kemungkinan pemerintah daerah untuk dapat meningkatkan anggaran pembangunan untuk 
mendorong tumbuhnya sektor riil; kedua, surplus anggaran yang ada dimanfaatkan untuk membiayai kegiatan yang produktif maka akan mampu menaikan PAD tahun berikutnya; ketiga, surplus anggaran juga bisa mengakibatkan adanya dana yang menganggur (idle fund) yang menyebabkan ekonomi tidak produktif dan tidak mendorong sektor riil untuk berkembang.

Dalam kondisi seperti ini pemerintah terdapat beberapa pilihan dalam memanfaatkan surplus anggaran yaitu: pertama, apabila targetnya untuk meningkatkan PAD maka pemerintah bisa melakukaninvestasi pada sektor-sektor yang produktif; kedua, apabila pemerintah ingin mempercepat pembangunan ekonomi masyarakat maka surplus anggaran bisa digunakan untuk belanja publik.

Pada prinsipnya analisis konversi pertama juga akan mencapai target nomor dua apabila investasi yang dilakukan produktif yang bisa memperbesar pendapatan tahun berikutnya pada akhirnya juga bisa digunakan untuk belanja publik.

Akhirnya dalam perencanaan pembangunan ini perlu adanya komitmen dan kesepakatan pemerintah Kota Jayapura dalam dua hal yaitu: (1) membuat suatu sistem insentif yang fair terhadap aparatur pemerintah yang menjadi bagian dari anggaran dan (2) pencapaian kinerja tertentu yang berhak mendapatkan rewards yang lebih besar. Dari semua ini dapat kita tarik rumusan bagaimana pemerintah seharusnya menerapkan value for money dalam anggaran sehingga pembangunan bisa berjalan efektif dan efisien.

\section{Rancangan Strategi Membangun dan Mengembangkan Pengelolaan Keuangan Daerah Kota Jayapura}

Rancangan strategi pembangunan keuangan daerah ini dibuat secara umum yang merupakan strategi rancangan pembangunan daerah, yang terdiri atas tigastrategi dasar yakni: (1) strategi keuangan, (2) strategi sumber daya manusia, (3) strategi operasional pemerintah.

Dari ketiga strategi dasar tersebut maka dapat dikurangi menjadi satu strategi utama yaitu strategi keuangan yang akan menjadi topik bahasan dalam rancangan ini. Proses alur pikir untuk rancangan ini merupakan suatu rangkaian yang bermula dari perumusan masalah, kemudian dilakukan analisis untuk mendapat hasil pembahasan, yang akhirnya melahirkan suatu rancangan program strategi membangun dan mengembangkan keuangan daerah.

Dalam rancangan ini tidak lepas dari tiga aspek yang terdapat dalam keuangan daerah yaitu pendapatan, belanja dan pembiayaan. Dari sisi pendapatan, bagaimana pemerintah daerah mencari sumber pendapatan yang ada disekeliling pemerintah untuk membiayai pembangunan daerah itu sendiri.

Dari aspek belanja, menggambarkan strategi pemerintah dalam mengalokasikan anggaran secara tepat yang mampu meningkatkan pertumbuhan sektor riil dan usaha-usaha produktif masyarakat.Ini berarti bahwa sebuah pengeluaran pemerintah $(\mathrm{G})$ harus dilakukan pada sektor yang mempunyai multiplier effect yang lebih besar dan menghindari pengeluaran $(\mathrm{G})$ yang tidak produktif. 
Pada sisi pembiayaan, bagaimana kreativitas pemerintah dalam mengambil keputusan untuk melakukan anggaran surplus ataupun defisit. Sebagaimana dalam analisis sebelumnya dalam konsep value for money bukan hanya sebagai fungsi dalam anggaran tapi adalah kelipatan dari pada uang yang dikeluarkan.

Pemerintahan daerah yang baik di era otonomi daerah adalah: (1) pemerintah daerah mempunyai inovasi bagaimana mencari sumber dana untuk pembiayaan pembangunan daerah.Kepala daerah di masa otonomi daerah harus merubah pola pikir yang selama ini berpikir bagaimana mengalokasikan sumber keuangan yang ada, maka sekarang adalah bagaimana mencari sumber keuangan secara cerdas tanpa membebani masyarakat dan mengalokasikan keuangan dengan efektif dan adil sehingga mampu meningkatkan kesejahteraan masyarakat; (2) bisa mengelola keuangan daerah dengan cara yang terukur dan bisa dipertanggungjawabkan kepada publik; (3) kompensasi yang diterima sesuai dengan kinerja yang diberikan. Seorang kepala daerah "seperti Chief Excecutive Officer" (CEO) dalam "perusahaan" besar yang bernama daerah. Ia tidak boleh menetapkan kompensasi untuk dirinya sendiri dengan sesuka hati tanpa ukuran keberhasilan kinerja yang jelas; (4) tindakan korupsi dengan berbagai macam cara adalah perbuatan terlarang dan berbahaya yang harus dijauhi karena akan berpengaruh terhadap kesejahteran seluruh masyarakat daerah.

Dalam pembahasan strategi keuangan daerah ini tidak terlepas dari tiga tinjauan yaitu pendapatan, belanja dan pembiayaan. Ketiga hal ini merupakan tiga sisi yang saling menguatkan dalam strategi keuangan.

Strategi ke 1: Membangun dan Mengembangkan Sistem Keuangan Daerah

Dalam mengoptimalkan pengelolaan keuangan daerah, maka perspektif perubahan yang diinginkan dalam pengelolaan keuangan daerah adalah:(1) pengelolaan keuangan daerah mengutamakan kepentingan masyarakat. Hal ini tidak saja terlihat pada besarnya porsi pengalokasian anggaran untuk kepentingan publik, tapi juga terlihat pada besarnya partisipasi masyarakat dalam perencanaan, pelaksanaan dan pengawasan keuangan daerah; (2) kejelasan misi pengelolaan keuangan daerah pada umumnya dan anggaran daerah pada khususnya; (3) desentralisasi pengelolaan keuangan dan kejelasan peran stakeholder terkait dalam pengelolaan anggaran; (4) kerangka hukum dan administrasi bagi pembiayaan, investasi dan pengelolaan uang berdasarkan kaidah mekanisme pasar, value for money, transparansi dan akuntabilitas; (5) kejelasan tentang biaya aparatur termasuk kedudukan keuangan DPRD, Wali Kota, pejabat PNS daerah, baik rasio maupun dasar pertimbangannya; (6) ketentuan tentang bentuk dan struktur anggaran, anggaran kinerja dan anggaran multi tahun; (7) prinsip pengadaan dan pengelolaan barang daerah yang lebih profesional; (8) prinsip akuntansi pemerintahan daerah, laporan keuangan, peran DPRD dan akuntan publik dalam pengawasan, pemberian opini dan rating kinerja anggaran dan transparansi informasi anggaran kepada publik; (9) aspek pembinaan dan pengawasan yang meliputi batasan pembinaan, peran asosiasi dan peran anggota masyarakat guna mengembangkan profesionalisme 
aparat pemerintah daerah; (10) pengembangan sistem informasi keuangan daerah untuk menyediakan anggaran yang akurat dan pengembangan komitmen pemerintah daerah terhadap penyebarluasan informasi sehingga memudahkan pelaporan dan pengendalian, sehingga mempermudah mendapatkan informasi; mengembangkan sistem keuangan yang bersifat online yang bisa diakses semua stakeholder sehingga partisipasi, koordinasi dan pengawasan lebih mudah oleh lembaga resmi maupun oleh masyarakat; (12) menggunakan teknologi informatika dalam sistem akuntansi keuangan daerah sehingga sangat memudahkan dalam pengoperasian dan pengontrolan; (13) menggunakan jasa perbankan yang ada untuk mengintermediasi antara wajib pajak dengan pemerintah, sehingga lebih mudah melakukan kontrol pendapatan setiap saat, serta membangun kepercayaan wajib pajak akan sampainya uang yang mereka serahkan ke kas daerah; (14) sistem keuangan daerah yang memberi ruang semua stakeholder dalam menetapkan anggaran (pemerintahan, swasta dan masyarakat) sehingga penentuan keuangan berdasarkan kebutuhan yang realistis tanpa hanya ditentukan sepihak oleh eksekutif dan legislatif.

Strategi ke 2: Mengoptimalkan Potensi Kehadiran Investor Lokal, Baru Keluar

Sering kali pemerintah meneropong pembangunan dari satu sudut pemerintah, sehingga terlupakan besarnya potensi yang ada di masyarakat termasuk potensi pendanaan pembangunan dan pertumbuhan ekonomi. Begitu juga ketika pemerintah memandang investasi dalam artian hanya investor yang mampu melakukan investasi dalam jumlah yang besar.Mind-trap ini membawa pola pemikiran pemerintah hanya pada satu sisi pengembangan daerah yang tergantung pada beberapa hal: pertama, memudahkan pelayanan publik dengan cara memberantas para calo dalam pengurusan surat menyurat (izin usaha dan peraturan lainnya) serta memudahkan persyaratan berinvestasi; pertama, persyaratan yang tidak berbelit-belit sehingga merangsang orang untuk berinvestasi di daerah; kedua, menyediakan kemudahan investasi dan usaha, sehingga pemerintah yang selama ini bersifat menunggu harus merubah sistem dengan sistem "jemput bola" yang merangsang masyarakat untuk berinvestasi dan berusaha.

Apabila investasi dan usaha daerah hidup secara langsung maupun tidak langsung akan memberikan kontribusi yang besar untuk pendapatan daerah dari pajak daerah dan retribusi daerah.Pelaksanaan yang sering muncul selama ini pemerintah bukannya menghidupkan investasi dan usaha di daerah tapi lebih sering sebagai penghambat berkembangnya usaha-usaha produktif masyarakat dengan perizinan yang berbelit dan berbagai macam pungutan liar (kanibalisme ekonomi). Aspek sosial lain berdampak positif dengan cara ini ialah: (1) menghindari kecemburuan sosial antara pendatang dengan penduduk lokal atau penduduk asli Papua seperti yang terjadi selama otonomi khusus ini di Kota Jayapura, karena kesenjangan sosial ekonomi; (2) masyarakat akan berlomba pada usaha yang produktif. 


\section{Strategi ke 3: Audit Kinerja Internal}

Keberadaan audit internal sangat bermanfaat dalam meningkatkan fungsi dan pengawasan internal: (1) merubah visi kantor Badan Pengawasan Daerah (BAWASDA) yang selama ini bekerja lebih banyak atas pesanan dan perintah Walikota dengan bekerja sesuai dengan visi dan target yang dimiliki; (2) memiliki tenaga auditor dan akuntan yang profesional untuk mendukung pekerjaan pengendalian keuangan pemerintah daerah. Bila belum punya tenaga profesional, bisa saja mengambil/bekerjasama dengan tenaga profesional dari luar; (3) melaksanakan review terhadap sistem pengendalian dan pengawasan internal dan sistem akuntansi pemerintahan daerah, sehingga tercapainya akuntabilitas pengelolaan keuangan daerah; (4) menetapkan standar keberhasilan sebagaimana sistem anggaran berbasis kinerja, sehingga pengawasan pembangunan, dapat terukur sesuai dengan indikator kinerja; (5) menertibkan administrasi pemerintahan daerah sampai level terbawah (kelurahan), sehingga memudahkan untuk melakukan pengontrolan keuangan dan administrasi: (6) membuat aturan main yang jelas dan tegas terutama segi penerimaan dan pengeluaran. Termasuk penerimaan yang langsung berkaitan dengan masyarakat sehingga tidak menambah beban ekonomi masyarakat (high cost economy); (7) melakukan pengawasan terhadap alur keluar masuk dana termasuk di dalamnya sistem penerimaan daerah yang seperti terabaikan selama ini dari pengawasan internal.

\section{SIMPULAN DAN REKOMENDASI}

\section{Simpulan}

1. Pengelolaan keuangan daerah di Kota Jayapura kurang efektif. Ada dua indikator yang dapat membuktikan hal tersebut. Pertama, penyusunan rencana pendapatan daerah ditetapkan dengan kurang perencanaan dan tanpa data potensi, sehingga rencana pendapatan cenderung underestimated yang berdampak besar terhadap pengalokasian penggunaan anggaran yang kurang sesuai dan terjadinya idle-fund. Kedua, dari sisi pengeluaran atau belanja menunjukkan kurangnya kesiapan pemerintah daerah, mulai dari proses penyusunan sampai pelaksanaan anggaran.

2. Kontribusi dana perimbangan yang sangat besar pada pendapatan daerah menunjukkan tingginya ketergantungan daerah Kota Jayapura terhadap pendapatan bagi hasil. Pengeluaran publik cenderung mengalami peningkatan, sehingga sangat memengaruhi besaran pengeluaran publik, sehingga dengan demikian pembangunan daerah tidak akan memberikan perubahan besar terhadap percepatan mengejar ketertinggalan wilayah dan masyarakat. Hal ini bertentangan dengan cita-cita otonomi khusus yang menginginkan terjadinya percepatan pembangunan daerah dan mendorong pembangunan nasional. Secara fungsional situasi ini juga menggambarkan gagalnya pemerintah dalam memberikan keadilan dalam pembangunan.

3. Penerapan sistem anggaran defisit oleh pemerintah daerah dengan cara mengoptimalkan perencanaan dalam tiga hal. Pertama, optimalisasi sumberdaya 
manusia dan alam dalam mengurangi ketergantungan pada dana perimbangan dengan melakukan pemetaan dan penataan pendapatan daerah.Kedua, pemerintah daerah diharapkan menyusun prioritas pembangunan daerah sehingga jelas pengalokasian anggaran sesuai konsep value for money. Ketiga, pemerintah daerah yang bersifat inovatif agar setiap tindakan mampu mendorong kegiatan ekonomi produktif.

\section{Saran}

1. Pemerintah Kota Jayapura diharapkan membangun sistem keuangan daerah yang berbasis online yang dimulai dari tahapan penerimaan, tahapan belanja dan pembiayaan sehingga akan mempermudah untuk melakukan evaluasi setiap pencapaian target dan melakukan perbaikan jika timbul kendala dalam tahun berjalan. Untuk kepentingan itu ada baiknya pemerintah daerah Kota Jayapura membuat e-government dengan mencontoh pada kabupaten-kabupaten lain di Indonesia yang sudah berhasil melaksanakannya.

2. Anggaran disusun dengan partisipatif dan transparan, dimana seluruh stakeholder bisa mengakses sekaligus memberikan masukan bagi pemerintah Kota Jayapura dalam mengelola keuangan daerah,

3. Pemerintah Kota Jayapura membuat sistem informasi pengelolaan anggaran terpadu, sehingga dapat mengoptimalkan potensi internal yang dimiliki dan merangsang investasi luar untuk masuk ke daerah,

4. Kemandirian fiskal dapat diciptakan dalam pengelolaan keuangan daerah isu strategis, oleh karena itu penelitian ini diharapkan memberikan manfaat bagi kelanjutan penelitian yang sama di masa mendatang serta memberikan solusi bagi pemerintah daerah dalam pengelolaan keuangan daerah.

\section{DAFTAR PUSTAKA}

Adi, P.H. 2005. Dampak desentralisasi fiskal terhadap pertumbuhan ekonomi. Jurnal Kritis Universitas Kristen Satya Wacana Salatiga.

APBD Kota Jayapura. 2002-2009. Rancangan APBD Kota Jayapura 2002-2009. Jayapura.

Aryanto, R. 2011. Analisis kemandirian keuangan daerah dan pertumbuhan ekonomi kabupaten/kota di Sumatera Selatan. Jurnal Ilmiah.Vol.3No.2.

Astuti, E. S., dan J. T. Haryanto. 2005. Analisis Dana Alokasi Umum (DAU) dalam era otonomi daerah studi kasus 30 Propinsi. Jurnal Manajemen Usahawan Indonesia.No.12: 38-48 Tahun XXXIV.

Dewa, I.G.B., dan Hery S. 2010. Evaluasi kinerja keuangan daerah pemerintah Provinsi Nusa Tenggara Barat tahun anggaran 2003-2007. Jurnal Ganec Swara Edisi Khusus (Desember).Vol.4 No.3. 
Enceng, P. M.W. 2008. Kajian terhadap penerimaan pendapatanasli daerah pemerintah daerah kabupaten/kota (studi kasus di Kabupaten Purworejo). Jurnal Ekonomi (Mei).Vol.13 No.1.

Galih, H.W., dan Nasikh. 2013. Analisis derajat desentralisasi fiskal keuangan daerah sebelum dan sesudah pelaksanaan kebijakan otonomi daerah di Kota Malang. Jurnal JESP.Vol.5 No.1.

Hutajulu, H., A. Sanggrangbano, dan A. K. Bonay.2012. Kajian efektivitas pengelolaan keuangan daerah Kabupaten Jayapura pada era otonomi khusus. Jurnal Ekonomi dan Bisnis Fakultas Ekonomi Universitas Udayana Bali(Agustus).Vol.1 No.1.

Hidayat, W. A. P., dan D. A. Harjito. 2007. Analisis kinerja keuangan kabupaten kota pemekaran di Sumatera Utara. Jurnal Ekonomi Pembangunan.Vol.12 No.3. Universitas Islam Indonesia. Yogyakarta.

Nanga, M. 2005. Analisis posisi fiskal kabupaten/kota di NTT: Adakah posisi fiskal pasca Otda lebih baik? Jurnal Kritis. Universitas Kristen Satya Wacana Salatiga.

Nazara, S., dan Nurkholis. 2006. Evaluasi pemekaran wilayah kabupaten/kota di Indonesia dalam era desentralisasi. Jurnal Kajian Ekonomi. Vol.5 No.2. Universitas Sriwijaya. Palembang.

Nugraeni. 2011. Analisis pengaruh Dana Alokasi Umum (DAU) Dana Alokasi Khusus (DAK) dan Pendapatan Asli Daerah (PAD) terhadap prediksi belanja daerah studi pada pemerintah daerah kabupaten/kota di Indonesia. Jurnal Akmenika UPY, Vol.8.

Prakosa, K. B. 2004. Analisis pengaruh Dana Alokasi Umum (DAU) dan Pendapatan Asli Daerah (PAD) terhadap prediksi belanja daerah, studi di wilayah Propinsi Jawa Tengah dan DIY. JAAI. Vol.8 No.2: 101-118.

Riyanto dan H. Siregar. 2005. Dampak dana perimbangan terhadap perekonomian daerah dan pemerataan antar wilayah. Jurnal Kebijakan Ekonomi. Vol.1 No.1 Yogyakarta.

Sodik, J., dan D. Nuryadin. 2005. Desentralisasi fiskal dan pertumbuhan ekonomi regional di Indonesia. Jurnal Ekonomi dan Studi Pembangunan (Oktober). Vol.6 No.2.

Sumarsono, H. 2009. Analisis kemandirian otonomi daerah: kasus Kota Malang (1999-2004). Jurnal JESP.Vol.1 No.1.

Tuasikal, A. 2008. Pengaruh DAU, DAK, PAD, dan PDRB terhadap belanja modal pemerintah daerah kabupaten/kota di Indonesia. Jurnal Telaah dan Riset Akuntansi(Juli).Vol.1 No.2: 142-155.

Undang-Undang Republik Indonesia Nomor 21 Tahun 2001. Tentang Otonomi Khusus Bagi Provinsi Papua.

Nomor 32 Tahun 2004. Tentang Pemerintahan Daerah. . Nomor 33 Tahun 2004. Tentang Perimbangan Keuangan Antara Pemerintahan Pusat Dan Daerah. 